\title{
Assessment of L-Citrulline, L-Arginine and L-Glutamic Acid Content in Selected Fruits, Vegetables, Seeds, and Nuts Sold in Markets in Nairobi City County, Kenya
}

\author{
Peninnah Mueni Mulwa, Wilson Njue, and Margaret Ng'ang'a
}

\begin{abstract}
Background: L-citrulline, L-arginine, and Lglutamic acid are amino acids which are vital in the human body. L-citrulline boosts immunity, combats sarcopenia, detoxifies the liver, and enhances male fertility. L-arginine boosts internal production of nitric oxide, prevents abnormal blood clotting and accelerates healing of wounds. L-glutamic acid cleanses the central nervous system and improves overall brain health. Deficiency of these amino acids can lead to accumulation of ammonia and impact negatively to the nervous systems of the human body. This study aimed to identify and determine the levels of $L$-citrulline, $L$-arginine, and $L$-glutamic acid in selected fruits, vegetables, nuts, and seeds sold in markets in Nairobi City County, Kenya using Liquid Chromatography- Mass Spectrometry (LC-MS).

Materials and Methods: Data was collected from 28 selected samples and data analysis was done using Statistical Analysis Software (SAS) version 9.4.

Results: LC-MS showed the presence of both L-arginine and L-citrulline in most fruits, vegetables, and nuts while L-glutamic acid was present in the seeds. The levels of the amino acids in the fruits and vegetables were in the following range: L-citrulline $(0.65-19.41 \mathrm{mg} / 100 \mathrm{~g})$ in the button mushroom, cucumber, pumpkin, amaranthus, and kales, $(3.16-3.79 \mathrm{mg} / 100 \mathrm{~g})$ in the watermelons and $(1.57-10.21 \mathrm{mg} / 100 \mathrm{~g})$ in the nuts. $\mathrm{L}$-arginine was in the range; $1.73-16.48 \mathrm{mg} / 100 \mathrm{~g}$ in the amaranthus, kales, button mushroom, butternut squash, and cucumber, 5.44-6.56 $\mathrm{mg} / 100 \mathrm{~g}$ in the watermelons and $0.93-10.73 \mathrm{mg} / 100 \mathrm{~g}$ in the nuts and L-glutamic acid $(0.013-0.28 \mathrm{mg} / 100 \mathrm{~g})$ in the seeds of pumpkin, butternut, and watermelons.

Conclusion: The results showed that locally available vegetables, fruits and nuts are rich in L-citrulline and Larginine.
\end{abstract}

Index Terms - fruits, L-arginine, L-citrulline, LC-MS, Lglutamic acid, nuts, seeds, and vegetables.

\section{INTRODUCTION}

Amino acids are building blocks of proteins and play critical roles in the human body such as; biosynthesis of hormones and neurotransmitters. Amino acids contain aminal $\left(-\mathrm{NH}_{2}\right)$ and carboxyl group $(-\mathrm{COOH})$ as their functional groups and a side chain $(\mathrm{R})$ which is specific for each amino acid. The amine group is a strong base that picks up $\mathrm{H}+$ from the carboxyl group to form a zwitter ion [1]. Amino acids are classified as essential and non-essential. Essential amino acids cannot be made by the human body and must be obtained from diets such as; meat, eggs, fish, and poultry while non-essential amino acids are synthesized by the body. However, if one is

Published on September 14, 2020

Peninnah Mueni Mulwa, Department of Chemistry, Kenyatta University, Kenya.

(e-mail: pennimueni@gmail.com) stressed, sick or not taking enough proteins and carbohydrates may not produce enough amino acids. Deficiency of amino acids can have negative impact to the nervous, reproductive, digestive, and immune systems of the human body [2]. Larginine and L-glutamic acid are among the 20 amino acids coded by the Deoxyribonucleic acid (DNA) while L-citrulline is not.

L-citrulline is an efficient anti-oxidant [3] and plays an important role in the treatment and management of diseases such as cancer, inflammatory, and cardiovascular diseases [4] It produces vascular endothelial growth factor (VEGF) which repairs and improves the function of the blood vessels within the corpus cavernosum which is a sponge-like region of erectile tissue that contains most of the blood in the penis during penile erection [5]. L-citrulline reduces blood pressure by increasing the dilation of blood vessels, improving blood flow [6]. Increase in the flow of blood increases the delivery of nutrients, oxygen, proteins, and other substances which help the body to function optimally. L-citrulline also helps the immune system to fight infections, boosts energy, and enhances both short term and long-term memory [4]. It raises the plasma L-arginine levels and reduces increased total number of white blood cells thus improving the condition of people suffering from the sickle cell disease [7]. L-citrulline supplementation has been assessed clinically and it gave positive results in the treatment of sarcopenia [8]. Sarcopenia is a disease characterized by decrease in muscle mass, strength, and function which occurs mostly to the elderly people. The condition is generally caused by low protein intake or protein metabolism alteration and reduced physical activity [9]. L-citrulline is mostly involved in the regulation of protein through activation of muscle protein synthesis and energy metabolism [10]. In the liver, L-citrulline removes phosphates and free radicals not needed by the kidneys. The radicals and phosphates usually make the kidneys work harder and over time causing damage to it [11].

Deficiency of L- citrulline in the body lead to improper functioning of the urea cycle which may lead to increase in ammonia concentrations, followed by coma, and eventually death [12]. L-arginine multiple health benefits in the human body including improving the immune function, detoxification, stimulation of growth hormone, and insulin that helps in provision of glucose in to the cells for growth and energy output [13]. Healthy adults can supply their own requirement for L-arginine but the rapidly growing teenagers, 
sick, and elderly people require it in their diet ${ }^{[14]}$. L-glutamic acid cleanses the central nervous system and improves overall brain health, attitude, and mental performance in the human body.[15] It reacts with ammonia in the muscles, kidneys, and brain tissues to form L-glutamine through enzyme glutamine synthase.[16] L-glutamic acid keeps a balanced acid- base ratio by separating off the toxic ammonia in the kidneys and causing it to react with acids and is excreted as urea. This also saves bicarbonate which is necessary for the neutralization of acids. It is converted in to glucose in the kidneys without affecting insulin levels thus combating the storage of fat from food which is usually helpful when trying to regulate body and it is an excitatory neurotransmitter in the central nervous system of mammals. A mixture of L-glutamic acid and aspartic acid is used as a cancer therapeutic agent because it induces death of tumor cells.[17] L-citrulline (1) is usually converted to L-arginine (2) within the body hence it is a precursor to L-arginine. L-glutamic acid (3) is also synthesized in the human body by different biosynthesis processes.<smiles>NC(=O)NCCC[C@H](N)C(=O)[O-]</smiles>

1<smiles>NC(=[NH2+])NCCCC([NH3+])C(=O)[O-]</smiles>
2<smiles>[NH3+][C@@H](CCC(=O)O)C(=O)[O-]</smiles>

Consumption of foods rich in L-citrulline and L-arginine have been linked to benefits such as treatment of sarcopenia [8], boosts the immune system [2], and treatment of cancer [18]. There is little or no information on levels of L-citrulline, L-arginine, and L-glutamic acid in fruits, vegetables, nuts and seeds sold in Kenyan markets. Hence, this study was aimed at assessing the levels of the amino acids in selected fruits, vegetables, nuts, and seeds.

\section{MATERIALS AND Methods}

Purposive sampling method was used in the study for collecting samples. Three fresh samples of each of the selected fruits, vegetables, and nuts were collected from Ngara, Githurai, and Muthurwa markets in Nairobi City County, Kenya. The samples were transported to Kenyatta University, Chemistry laboratory for further preparation and analysis.

\section{A. Study design}

Experimental.

\section{B. Study location}

Markets in Nairobi County, Kenya geographical coordinates of study are degrees, longitude, latitude.

\section{Study duration}

April 2018 to October 2019.

\section{Sample size}

28 fruits, vegetables, seeds, and nuts.

\section{E. Sample size calculation}

The sample size was estimated on the basis of a single proportion design. The target fruits, vegetables, seeds, and nuts were randomly bought from the big markets where most farmers sell their produce from their farms. We assumed the confidence interval of $10 \%$ and confidence level of $95 \%$.

\section{F. Subjects and selection methods}

The study samples were obtained from Muthurwa, Ngara, and Githurai markets in Nairobi City County, Kenya. This is because many farmers sell their farm produce in these markets on whole sale.

\section{G. Procedure methodology}

Accurately weighed $10.0 \mathrm{mg}$ of crystalline L-citrulline, Larginine, and L-glutamic acid were each dissolved in deionized water and made up to $10.0 \mathrm{~mL}$ in volumetric flask to give $1000 \mu \mathrm{g} / \mathrm{mL}$ standard stock solutions of each. Working solutions were prepared by serial dilutions of the stock solutions to obtain appropriate concentrations of $1 \mu \mathrm{g} / \mathrm{mL}$ $60 \mu \mathrm{g} / \mathrm{mL}$ and were stored at $4^{\circ} \mathrm{C}$ before use.

The collected individual samples were thoroughly mixed to form a uniform sample then cleaned to remove any dust particles. The samples were then extracted according to the protocol described by Agnes and Penelope [19] with slight modification. $50 \mathrm{~mL}$ of methanol and $6 \mathrm{M}$ aqueous hydrochloric acid in the ratio of 9:1 was added to $100 \mathrm{~g}$ of the prepared samples in $250 \mathrm{~mL}$ conical flask and extracted in a flat- water bath shaker at $25{ }^{\circ} \mathrm{C}$ for one hour. The samples were then heated at $70{ }^{\circ} \mathrm{C}$ in an oven (WTR binder company, Germany) for four hours then allowed to cool to room temperature. The extracts were then filtered under vacuum and washed twice using $5 \mathrm{~mL}$ of the extraction solvent (methanol and 6M aqueous $\mathrm{HCl}$ in the ratio 9:1). The filtrates were then concentrated using a rotary evaporator, transferred in to vials and stored at $-20{ }^{\circ} \mathrm{C}$. The procedure was repeated to all the prepared samples. The extracted samples were Cleaned-up using reversed phase SPE columns packed with $\mathrm{C}_{18}$ material, according to the protocol highlighted by Boyd and his friends [20]. Columns were conditioned with $5 \mathrm{~mL}$ of deionized water before loading the sample and washed twice with $5 \mathrm{~mL}$ of methanol and $6 \mathrm{M}$ aqueous $\mathrm{HCl}(9: 1)$. The sample was loaded and eluted using $5 \mathrm{~mL}$ of methanol and $6 \mathrm{M}$ aqueous $\mathrm{HCl}$ (9:1). The resulting eluents were concentrated for 20 minutes. This procedure was repeated for all the samples.

\section{H. Statistical analysis}

Data analyzed using SAS version 9.4. Student's $t$-test was used to determine the significant differences between mean values of two continuous variables and one-way analysis of variance (ANOVA), $p<0.005$ ) at $95 \%$ confidence level.

\section{RESUlTS AND DISCUSSION}

\section{A. Calibration curves}

Calibration curves shown in Fig. 1-3 were obtained by plotting peak areas $\left(\mathrm{mm}^{2}\right)$ against the concentrations of the 
standards $(\mu \mathrm{g} / \mathrm{mL})$. The concentrations of the standards ranged as follows: L-citrulline, $1.00-45.00 \mu \mathrm{g} / \mathrm{mL}$, Larginine, $1.00-60.00 \mu \mathrm{g} / \mathrm{mL}$, and L-glutamic acid, 0.01-1.00 $\mu \mathrm{g} / \mathrm{mL}$. The calibration curves of the standards were used to determine the levels of amino acids from sample extracts.

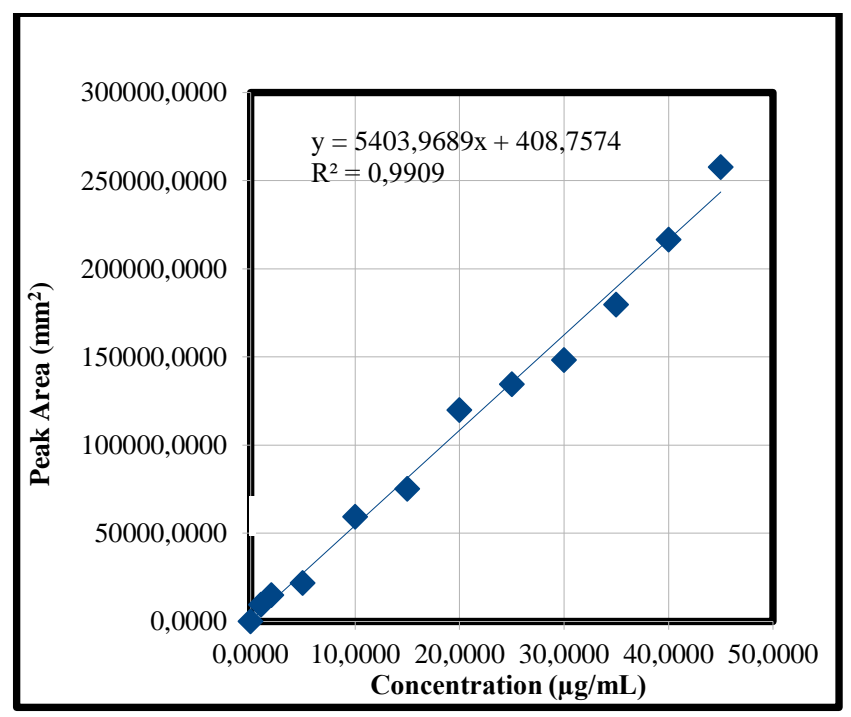

Fig 1. Calibration curve for L-citrulline standard.

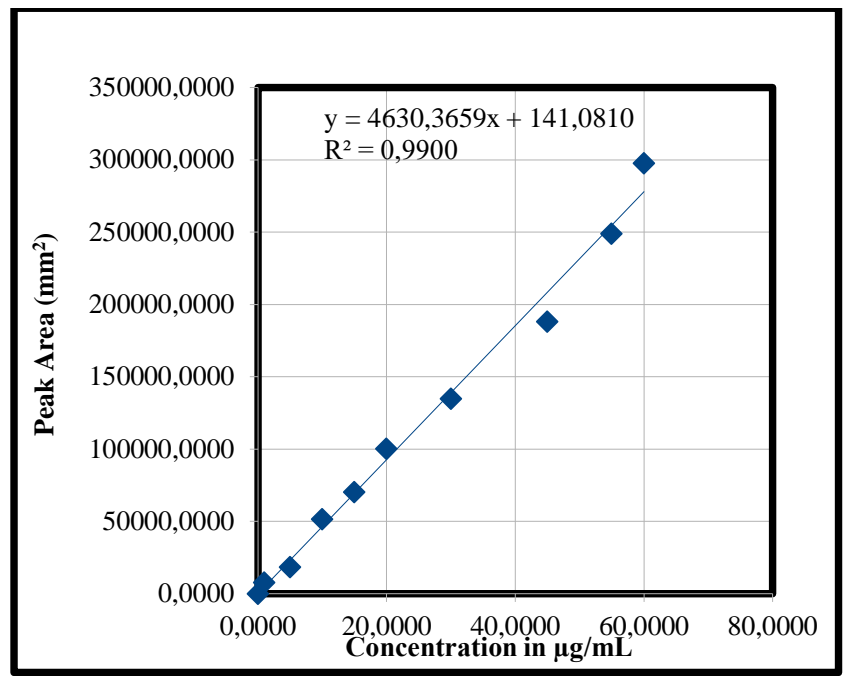

Fig 2. Calibration curve for L-arginine standard.

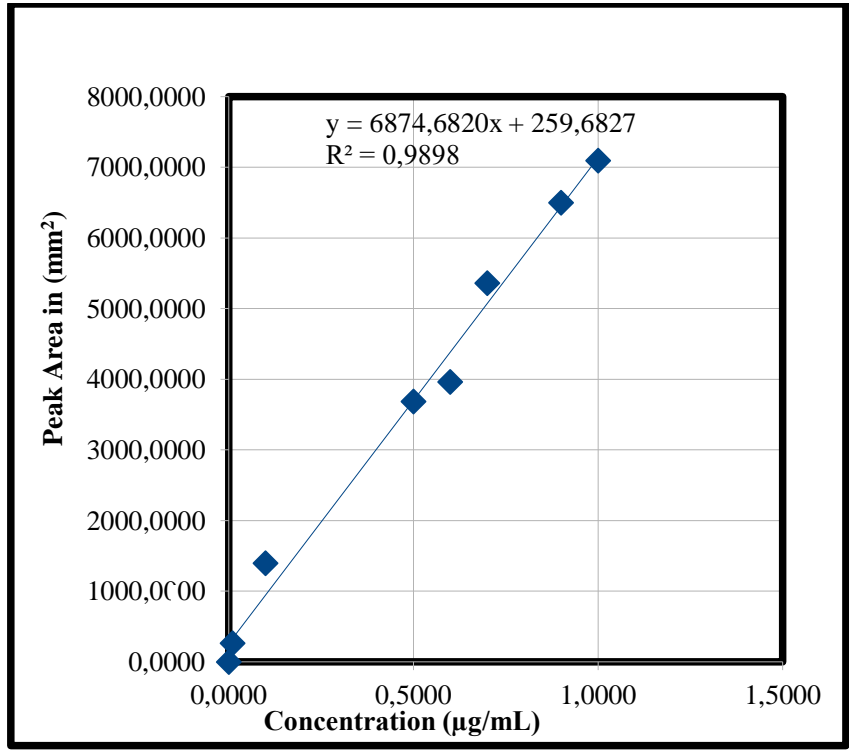

Fig 3. Calibration curve of L-glutamic acid standard.
The $\mathrm{R}^{2}$ values ranged between 0.9898 and 0.9909 which indicated that the calibration curves were linear over the concentration range of the standards.

B. Mean Levels of the amino acids in Selected Fruits, Vegetables, Nuts and Seeds

Liquid Chromatography - Mass Spectrometry (LC-MS)

(Agilent-Germany, micromass ZQ waters 2000-UK) was used to obtain mean levels of L-citrulline, L-arginine and Lglutamic acid in selected fruits and vegetables.

Table 1 and 2 shows the levels for L-arginine, L-citrulline and L-glutamic acid in fruits and vegetables on fresh and dry weight basis.

TABLE I: MEAN LEVELS OF THE AMINO ACIDS IN FRUITS AND VEGETABLES (FRESH WEIGHT)

\begin{tabular}{lccc}
\hline \multicolumn{1}{c}{ Variety } & L-citrulline & L-arginine & $\begin{array}{c}\text { L-glutamic } \\
\text { acid }\end{array}$ \\
\hline Button mushroom & $4.05 \pm 0.08^{\mathrm{a}}$ & $1.02 \pm 0.008^{\mathrm{e}}$ & nd \\
Cucumber & $3.64 \pm 0.02^{\mathrm{b}}$ & $1.44 \pm 0.05^{\mathrm{d}}$ & nd \\
Amaranthus & $1.40 \pm 0.005^{\mathrm{c}}$ & $4.45 \pm 0.08^{\mathrm{b}}$ & nd \\
Charleston gray & $1.16 \pm 0.02^{\mathrm{d}}$ & $4.51 \pm 0.12^{\mathrm{b}}$ & nd \\
watermelon & & & \\
Sugar baby & $0.77 \pm 0.03^{\mathrm{e}}$ & $2.93 \pm 0.07^{\mathrm{c}}$ & nd \\
watermelon & nd & nd & nd \\
Horned melon & $0.49 \pm 0.02^{\mathrm{f}}$ & $5.40 \pm 0.28^{\mathrm{a}}$ & nd \\
Kales & $0.26 \pm 0.003^{\mathrm{f}}$ & $0.31 \pm 0.003^{\mathrm{f}}$ & $0.04 \pm 0.03^{\mathrm{a}}$ \\
Pumpkin & $0.46 \pm 0.02^{\mathrm{f}}$ & $4.87 \pm 0.17^{\mathrm{b}}$ & nd \\
Butternut squash &
\end{tabular}

i. Means in the table on the same column with the same small letters, superscripted shows the values are not significantly different at $95 \%$ confidence level.

ii. Means in a column followed by a different letter are significantly different (Tukey's test $P<0.05$ ).

iii. Nd- Not detected.

TABLE II: SHOWS THE CONTENTS OF THE AMINO ACIDS (MG/ 100G) IN

\begin{tabular}{lccc}
\multicolumn{4}{c}{ FRUITS AND VEGETABLES BASED ON DRY WEIGHT } \\
\hline \multicolumn{1}{c}{ Variety } & L-citrulline & L-arginine & L-glutamic acid \\
\hline Cucumber & $19.41 \pm 0.19^{\mathrm{a}}$ & $1.73 \pm 0.02^{\mathrm{e}}$ & $0.01 \pm 0.0004^{\mathrm{c}}$ \\
Button mushroom & $14.73 \pm 0.16^{\mathrm{b}}$ & $6.85 \pm 0.11^{\mathrm{c}}$ & $0.08 \pm 0.001^{\mathrm{b}}$ \\
Pumpkin & $10.75 \pm 0.10^{\mathrm{c}}$ & $12.78 \pm 0.27^{\mathrm{b}}$ & $0.28 \pm 0.005^{\mathrm{a}}$ \\
Charleston gray & $3.79 \pm 0.12^{\mathrm{d}}$ & $6.56 \pm 0.1^{\mathrm{c}}$ & $\mathrm{nd}$ \\
watermelon & & & \\
Sugar baby & $3.16 \pm 0.12^{\mathrm{e}}$ & $5.44 \pm 0.1^{\mathrm{d}}$ & $\mathrm{nd}$ \\
watermelon & $\mathrm{nd}$ & $\mathrm{nd}$ & $\mathrm{nd}$ \\
Horned melon & $1.78 \pm 0.01^{\mathrm{f}}$ & $5.82 \pm 0.11^{\mathrm{d}}$ & $0.0012 \pm 0.00^{\mathrm{d}}$ \\
Amaranthus & $1.20 \pm 0.01^{\mathrm{g}}$ & $12.59 \pm 0.05^{\mathrm{b}}$ & nd \\
Kales & $0.65 \pm 0.01^{\mathrm{h}}$ & $16.48 \pm 0.03^{\mathrm{a}}$ & nd \\
Butternut squash & &
\end{tabular}

i. Means on the same column with the small letters superscripted indicates the values were not significantly different at $95 \%$ confidence level. ii. Means in a column followed by a different letter are significantly different (Tukey's test $P<0.05$ ).

iii. Nd- Not detected.

The concentrations of L-citrulline in the samples on fresh and dry weight basis were as follows: cucumber $(3.64 \pm 0.02$, $19.41 \pm 0.19 \mathrm{mg} / 100 \mathrm{~g})$, button mushroom $(4.05 \pm 0.08$, $14.73 \pm 0.16 \mathrm{mg} / 100 \mathrm{~g}$ ), Charleston Gray watermelon $(1.16 \pm 0.02,3.79 \pm 0.12 \mathrm{mg} / 100 \mathrm{~g})$, Sugar-Baby watermelon $(0.77 \pm 0.03,3.16 \pm 0.12 \mathrm{mg} / 100 \mathrm{~g})$, and pumpkin $(0.26 \pm 0.003$, $10.75 \pm 0.10 \mathrm{mg} / 100 \mathrm{~g})$. The values were significantly higher $(P<0.05)$ than those contained in amaranthus $(1.40 \pm 0.005$, $1.78 \pm 0.01 \mathrm{mg} / 100 \mathrm{~g})$, kales $(0.49 \pm 0.02,1.20 \pm 0.01 \mathrm{mg} / 100 \mathrm{~g})$, and butternut squash $(0.46 \pm 0.02,0.65 \pm 0.01 \mathrm{mg} / 100 \mathrm{~g})$.

In Charleston Gray watermelon $(1.16 \pm 0.02$ fresh weight, $3.79 \pm 0.12$ dry weight) L-citrulline content was significantly higher $(P<0.05)$ than in Sugar Baby watermelon $(0.77 \pm 0.03$ fresh weight, $3.16 \pm 0.12$ dry weight). The significant difference in concentrations of L-citrulline in the vegetables 
and fruits could be attributed to differences in the varieties, chemical, and environmental conditions [21]. The mean concentrations of L-citrulline in the selected fruits and vegetables are below the daily recommended intake $(3 \mathrm{~g} / \mathrm{kg}$ body weight) for athletes [22] but within RNI $(0.18 \mathrm{~g} / \mathrm{kg}$ body weight) for healthy people [23].

The following were the mean levels of L-arginine in the samples on fresh and dry weight basis: butternut squash $(4.87 \pm 0.17,16.48 \pm 0.03 \mathrm{mg} / 100 \mathrm{~g})$, pumpkin $(0.31 \pm 0.003$, $12.78 \pm 0.27 \mathrm{mg} / 100 \mathrm{~g})$ and kales $(5.40 \pm 0.28$, $12.59 \pm 0.05 \mathrm{mg} / 100 \mathrm{~g})$. The difference in the concentrations of L-arginine in the vegetables could have been due to weather, geographical conditions, and varieties of vegetables.[19] The mean concentrations of L-arginine in the Kenyan fruits and vegetables are below the daily recommended nutrition intake (RNI) ( $3 \mathrm{~g} / \mathrm{kg}$ body weight) in healthy persons [24].

The mean levels of L-glutamic acid in the vegetables on fresh and dry weight basis were as follows: pumpkin recorded significantly higher $(P<0.05)$ values $\quad(0.04 \pm 0.03$, $0.28 \pm 0.005 \mathrm{mg} / 100 \mathrm{~g}$ ) than button mushroom (nd, $0.08 \pm 0.001 \mathrm{mg} / 100 \mathrm{~g}$ ), cucumber (nd, $0.01 \pm 0.0004 \mathrm{mg} / 100 \mathrm{~g}$ ), and amaranthus (nd, $0.0012 \pm 0.00 \mathrm{mg} / 100 \mathrm{~g}$ ). L-glutamic acid was not detected in kales, watermelons, butternut squash, and horned melon. However, these levels were relatively lower than those reported in earlier studies. The difference in the concentrations of L-glutamic acid could be as a result of climatic, geographical, chemical, and variety factors [25]. The levels of L-glutamic acid in the vegetables are below the recommended nutrition intake $(500-3000 \mathrm{mg} / \mathrm{kg}$ body weight)[26].

The overall mean concentration of the three amino acids in the dry fruit and vegetable samples were significantly higher $(P<0.05)$ than in the fresh fruit and vegetable samples. This difference can be attributed to the high water content in the fresh samples while the dry samples did not contain water. The three amino acids were not detected in horned melon, a common fruit in our local markets with claims of medicinal value for body vitality [27].

The mean levels of the amino acids in the seeds are shown in Table III.

\begin{tabular}{lccc}
\multicolumn{4}{c}{ TABLE III: MEAN LEVELS OF THE AMINO ACIDS IN SEEDS } \\
\hline \multicolumn{1}{c}{ Variety } & L-citrulline & L-arginine & L-glutamic acid \\
\hline Pumpkin seeds & nd & nd & $0.15 \pm 0.003^{\mathrm{a}}$ \\
Butternut seeds & nd & nd & $0.06 \pm 0.001^{\mathrm{b}}$ \\
$\begin{array}{l}\text { Sugar Baby water } \\
\text { melon seeds }\end{array}$ & nd & nd & $0.014 \pm 0.0003^{\mathrm{c}}$ \\
$\begin{array}{l}\text { Charleston Gray } \\
\text { water melon seeds }\end{array}$ & nd & nd & nd \\
Horned melon & nd & nd & nd
\end{tabular}

\footnotetext{
i. Means in a column followed by a different small letter superscripted are significantly different (Tukey's test $P<0.05$ )

ii. Nd- Not detected.
}

L- arginine and L- citrulline could not be detected in all the samples (Table III). L- glutamic acid was detected in pumpkin seeds (0.15 \pm 0.003$)$, Butternut $(0.06 \pm 0.001)$ seeds, and Sugar Baby watermelon seeds $(0.014 \pm 0.0003)$. L-glutamic acid could not be detected in Charleston Gray watermelon seeds and horned melon seeds. This can be attributed to levels being lower than the limit of detection of L-arginine $(0.008 \mu \mathrm{g} / \mathrm{mL})$,
L-citrulline $(0.005 \mu \mathrm{g} / \mathrm{mL})$ and L-glutamic acid $(0.0002$ $\mu \mathrm{g} / \mathrm{mL}$ ) of the LC-MS machine used.

The concentrations of the amino acids in cashew nuts, peanuts and macadamia nuts are shown in Table IV.

TABLE IV: MEAN CONCENTRATIONS OF THE AMINO ACIDS (MG/100G) IN CASHEW NUTS, PEANUTS AND MACADAMIA NUTS

\begin{tabular}{|c|c|c|c|}
\hline Nuts & L-citrulline & L-arginine & L-glutamic acid \\
\hline $\begin{array}{l}\text { Cashew nuts (dry } \\
\text { weight) }\end{array}$ & $3.07 \pm 0.04^{\mathrm{c}}$ & $4.22 \pm 0.06^{\mathrm{d}}$ & nd \\
\hline $\begin{array}{l}\text { Cashew nuts } \\
\text { (fresh weight) }\end{array}$ & $2.19 \pm 0.03^{\mathrm{d}}$ & $8.94 \pm 0.45^{\mathrm{a}}$ & nd \\
\hline $\begin{array}{l}\text { Peanuts (dry } \\
\text { weight) }\end{array}$ & $3.81 \pm 0.06^{\mathrm{b}}$ & $2.86 \pm 0.27^{\mathrm{e}}$ & nd \\
\hline $\begin{array}{l}\text { Peanuts (fresh } \\
\text { weight) }\end{array}$ & $1.57 \pm 0.02^{\mathrm{e}}$ & $6.57 \pm 0.09^{\mathrm{b}}$ & $0.092 \pm 0.001^{\mathrm{b}}$ \\
\hline Macadamia nuts & $6.93 \pm 2.9^{\mathrm{a}}$ & $4.59 \pm 5.4^{\mathrm{c}}$ & $0.24 \pm 0.004^{\mathrm{a}}$ \\
\hline
\end{tabular}

The following were the mean concentrations of L-citrulline in the nuts on fresh and dry weight basis: cashew nuts $(2.19 \pm 0.03,3.07 \pm 0.04)$, peanuts $(1.57 \pm 0.02,3.81 \pm 0.06)$, and macadamia nuts $(6.93 \pm 2.9 \mathrm{mg} / 100 \mathrm{~g})$. This trend is comparable to that found in fruits and vegetables probably due to high water activity in the fresh weight unlike in the dry weight. The mean levels of L-arginine in the nuts on fresh and dry basis were as follows: cashew nuts $(8.94 \pm 0.45$, $4.22 \pm 0.06)$, peanuts $(6.57 \pm 0.09,2.86 \pm 0.27)$, and macadamia nuts $(4.59 \pm 5.4)$. The trend is different from that found in fruits and vegetables. L-arginine being basic dissolves in water and as the water is being evaporated, it takes away some amount of the amino acid causing the levels of L-arginine in the nuts on dry weight basis to be lower than on fresh weight basis. On fresh weight basis, L-citrulline levels $(1.57 \pm 0.02$ $2.19 \pm 0.03 \mathrm{mg} / 100 \mathrm{~g})$ are significantly lower $(P<0.05)$ than the L-arginine levels $(6.57 \pm 0.09-8.94 \pm 0.45 \mathrm{mg} / 100 \mathrm{~g})$. This is because L-citrulline is neutral and dissolves in oil. As the oil is being extracted, it takes away some amount of Lcitrulline which is not the case in L-arginine which is basic and does not dissolve in oil. The mean concentrations of $\mathrm{L}$ glutamic acid in the samples were as follows: macadamia nuts $(0.24 \pm 0.004 \mathrm{mg} / 100 \mathrm{~g})$ had significantly higher levels $(P<0.05)$ than peanuts $(0.092 \pm 0.001 \mathrm{mg} / 100 \mathrm{~g})$. L-glutamic acid was not detected in cashew nuts may be due the levels being lower than the limit of detection of L-glutamic acid $(0.0002 \mu \mathrm{g} / \mathrm{mL})$. Levels of L-citrulline, L-arginine, and Lglutamic acid in the nuts (table IV) were below the recommended nutrition intake (RNI). The RNI's are; Lcitrulline (3-6 g/kg body weight), [23] L-arginine (5-10 g/kg body weight) [24] and L-glutamic acid $(0.5-3 \mathrm{~g} / \mathrm{kg}$ body weight)[26]. The levels of the three amino acids are slightly lower than the levels reported in literature. The difference in the concentrations could be attributed to method of analysis, chemotypic, genetic diversity, weather, geographical conditions, and varieties of vegetables [19]. A study conducted in U.S.A by Wayne[28] revealed that, vegetables such as; cucumber, pumpkin, butternut squash, and gourds in the family of cucurbitaceae are good sources of these amino acids. In Malaysia, a study done by Ridwan et al [29] reported that the levels of L-citrulline were in the range of 43.81 $45.02 \mathrm{mg} / \mathrm{g}$ and L-arginine, 3.39-11.14 $\mathrm{mg} / \mathrm{g}$ in the watermelons. Whereas L-citrulline content reported by Laila 
et al [30] of Malaysia was lower (3.9-28.5 mg/g) than the levels (43.81-45.02 mg/g) reported by Ridwan et al [29].

\section{CONCLUSION}

This study analyzed the presence and levels of L-arginine, L-citrulline and L-glutamic acid in cucumber, pumpkin, butternut squash, Charleston gray watermelon, sugar baby watermelon, amaranthus, kales, button mushroom, macadamia nuts, pea nuts and cashew nuts sold in markets in Nairobi city County, Kenya. L-citrulline and L-arginine were present in button mushroom, cucumber, pumpkin, watermelons, macadamia nuts and cashew nuts at varied concentrations with the cucurbitaceae family recording significantly higher $(P<0.05)$ levels of L-citrulline than amaranthus and kales. The fruits and vegetables on dry weight basis had significantly higher levels $(P<0.05)$ of the three amino acids than on fresh weight basis. This could be attributed to dilution of the amino acids by water in fresh fruits and vegetables since the amino acids are polar. The levels of L-arginine and L- citrulline in Charleston gray watermelon were significantly higher $(P<0.05)$ than in sugar baby watermelon. Overall, the analyzed fruits, vegetables and nuts sold in markets in Nairobi city County, Kenya are good sources of L-citrulline whose levels are within the recommended nutrition intake levels for persons suffering from high blood pressure (1.5-6 g/day). Seeds are poor sources of L-arginine and L-citrulline but good sources of Lglutamic acid. Though horned melon is a popular fruit in the local market considered to be of medicinal value, did not contain any of the three amino acids.

\section{ACKNOWLEDGMENT}

The authors thank the department of Chemistry at Kenyatta University for providing laboratory space, chemicals, apparatus and instruments.

\section{REFERENCES}

[1] W. D. Price, R. A. Jockusch, and E. R. Williams, "Is arginine a zwitterion in the gas phase?," J. Am Chem Soc. doi:10.1021/ja9711627, Vol. 119, no.49, pp.11988-11989, 1997.

[2] G. Wu, "Amino acids: metabolism, functions, and nutrition," Amino Acids, doi:10.1007/s00726-009-0269-0, Vol.37, no.1, pp.1-17, 2009.

[3] Y-Z. Fang, S. Yang, and G. Wu, "Free radicals, antioxidants, and nutrition," Nutrition, Vol. 18, no. 10, pp. 872-879, 2002.

[4] E. Curis, I. Nicolis, and C. Moinard, "Almost all about citrulline in mammals," Amino Acids, doi:10.1007/s00726-005-0235-4, Vol. 29, no.3 pp.177-205, 2005.

[5] K. Komori, A. Tsujimura, and T. Takao, "Nitric oxide synthesis leads to vascular endothelial growth factor synthesis via the NO/cyclic guanosine 3',5'-monophosphate (cGMP) pathway in human corpus cavernosal smooth muscle cells," J. Sex Med, doi:10.1111/j.17436109.2008.00772.x, Vol.5, no.7, pp. 1623-1635, 2008.

[6] A. Figueroa, J. A. Trivino, M. A. Sanchez-Gonzalez, and F. Vicil, "Oral L-citrulline supplementation attenuates blood pressure response to cold pressor test in young men," Am J. Hypertens. doi:10.1038/ajh.2009.195, Vol. 23, no.1, pp.12-16, 2010.

[7] W. H. Waugh, C. W. $3^{\text {rd }}$ Daeschner, B. A. Files, M. E. McConnell, and S. E. Strandjord. "Oral citrulline as arginine precursor may be beneficial in sickle cell disease: early phase two results," J. Natl Med Assoc. 2001;93(10):363-371.

[8] S. Bahri, N. Zerrouk, and C. Aussel, "Citrulline: from metabolism to therapeutic use," Nutrition, doi:10.1016/j.nut.2012.07.002, Vol. 29, no.3, pp. 479-484, 2013.

[9] A. J. Cruz-Jentoft, J. P. Baeyens, and J. M. Bauer," Sarcopenia: European consensus on definition and diagnosis: Report of the
European Working Group on Sarcopenia in Older People," Age Ageing, doi:10.1093/ageing/afq034. Vol. 39, no.4, pp. 412-423, 2010.

[10] L. Cynober, C. Moinard, J-P De Bandt and The 2009 ESPEN Sir David Cuthbertson, "Citrulline: a new major signaling molecule or just another player in the pharmaconutrition game?," Clin Nutr. doi:10.1016/j.clnu.2010.07.006. Vol. 29, no.5, pp. 545-551, 2010.

[11] K. Akashi, C. Miyake, and A. Yokota, "Citrulline, a novel compatible solute in drought-tolerant wild watermelon leaves, is an efficient hydroxyl radical scavenger," FEBS Lett. doi:10.1016/s00145793(01)03123-4. Vol. 508, no.3, pp. 438-442, 2000.

[12] P. Crenn, K. Vahedi, A. Lavergne-Slove, L. Cynober, C. Matuchansky, and B. Messing, "Plasma citrulline: A marker of enterocyte mass in villous atrophy-associated small bowel disease," Gastroenterology. doi:10.1016/s0016-5085(03)00170-7, Vol.124, no.5, pp. 1210-1219, 2003.

[13] J. A. Kanaley, "Growth hormone, arginine and exercise," Curr Opin Clin Nutr Metab Care, doi:10.1097/MCO.0b013e3282f2b0ad, Vol.11, no.1. pp. 50-54, 2008.

[14] G. Wu, L. A. Jaeger, F. W. Bazer, and J. M. Rhoads, "Arginine deficiency in preterm infants: biochemical mechanisms and nutritional implications," J. Nutr Biochem, doi:10.1016/j.jnutbio.2003.11.010, Vol. 15, no.8, pp. 442-451, 2004.

[15] B. S. Meldrum, "Glutamate as a neurotransmitter in the brain: review of physiology and pathology," J. Nutr. doi:10.1093/jn/130.4.1007S, Vol. 130, no.4S Suppl, pp. 1007S-1015S, 2000.

[16] C. Kulkarni, K. Kulkarni, and B. Hamsa, "L-Glutamic acid and glutamine: Exciting molecules of clinical interest," Indian J. Pharmacol. doi:10.4103/0253-7613.16210, Vol.37, no.3, pp. 148-154, 2005.

[17] W. Ren, Y. Li, and X. Yu, "Glutamine modifies immune responses of mice infected with porcine circovirus type 2," $\mathrm{Br} J$. Nutr. doi:10.1017/S0007114512006101, Vol. 110, no.6, pp. 1053 1060,2013

[18] Y. Yamaguchi, K. Yamamoto, Y. Sato, S. Inoue, T. Morinaga, and E. Hirano, "Combination of aspartic acid and glutamic acid inhibits tumor cell proliferation," Biomed Res. doi:10.2220/biomedres.37.153, Vol. 37, no.2, pp. 153-159, 2016.

[19] A. M. Rimando, and P. M. Perkins-Veazie, "Determination of citrulline in watermelon rind," J. Chromatogr A doi:10.1016/j.chroma.2005.05.009, Vol.1078, no.1-2, pp.196-200, 2005.

[20] P. L. Urban, "Quantitative mass spectrometry: an overview," Philos Trans A Math Phys Eng Sci, doi:10.1098/rsta.2015.0382, Vol. 374, no. 2079, pp. 20150382, 2016.

[21] R. Davis Angela, Webber, L. Charles, W. Fish Wayne, Wehner, C. Todd, S. King, Perkins-Veazie, ARA-D. Penelope, "L- citrulline levels in watermelon cultigens tested in two environments," Hortscience, Vol. 46, no.12, pp. 1572-1575, 2011.

[22] B. Giannesini, Y. Le Fur, P. J. Cozzone, M. Verleye, M-E. Le Guern, and D. Bendahan, "Citrulline malate supplementation increases muscle efficiency in rat skeletal muscle," Eur J. Pharmacol, doi:10.1016/j.ejphar.2011.05.068, Vol. 667, no.1-3, pp.100-104, 2011.

[23] C. Rouge, C. Des Robert, and A. Robins, "Manipulation of citrulline availability in humans," Am J. Physiol Gastrointest Liver Physiol, doi:10.1152/ajpgi.00289, Vol.293, no.5, pp.1061-1067, 2007.

[24] S. R. Collier, E. Collins, and J. A. Kanaley, "Oral arginine attenuates the growth hormone response to resistance exercise," J. Appl Physiol, doi:10.1152/japplphysiol.00285.2006, Vol. 101, no.3, pp.848-852, 2006.

[25] H. Haufe, K. Muschter, J. Siegert, and H. Böttcher, dd. EndNote.

[26] H. Osiecki, "The Role of Chronic Inflammation in Cardiovascular Disease and its Regulation by Nutrients," Altern Med Rev, Vol. 9, pp. 32-53, 2004.

[27] O. Sodipo, A. Kwaghe, and U. Sandabe, "Uses of Cucumis metuliferus: A Review," Cancer Biol, Vol. 55, pp. 24-34, 2015.

[28] W. Fish, "A Reliable Methodology for Quantitative Extraction of Fruit and Vegetable Physiological Amino Acids and Their Subsequent Analysis with Commonly Available HPLC Systems," Food Nutr Sci, doi:10.4236/fns.2012.36115, pp. 03, 2012.

[29] R. Ridwan, H. R. Abdul Razak, M. Adenan, and W. Saad, "Development of Isocratic RP-HPLC Method for Separation and Quantification of L-Citrulline and L-Arginine in Watermelons," Int J. Anal Chem, doi:10.1155/2018/4798530, pp.1-9, 2018.

[30] L. D. Rochmatika, H. Kusumastuti, and S. Marwati, "An Analysis of Antioxidants Activity in Face Mask with Basic Ingredients of a Watermelon, Int Conf Chem Agric Med Sci, pp.10-12, 2013. 
Peninnah Mulwa was born on $16^{\text {th }}$ Oct, 1976 in Machakos County, Kenya. She has a Masters in science- Chemistry, 2020 from Kenyatta University, Bachelors in Education Science (Chemistry and Physics), 2012 from Catholic University of Eastern Africa and Diploma in Education Science (Chemistry and Physics), 1999 from Kagumo Teachers Training College.

She is a scholar and a scientific researcher ever curious of getting new findings. She is currently working with Teachers' Service Commission as a teacher of Chemistry and Physics. 